\title{
WestVirginiaUniversity
}

THE RESEARCH REPOSITORY @ WVU

Volume 110 | Issue 1

Article 23

September 2007

\section{Is Public Reason Counterproductive?}

Eduardo M. Peñalver

Cornell Law School

Follow this and additional works at: https://researchrepository.wvu.edu/wvlr

Part of the Law and Philosophy Commons, Law and Politics Commons, and the Law and Society

Commons

\section{Recommended Citation}

Eduardo M. Peñalver, Is Public Reason Counterproductive?, 110 W. Va. L. Rev. (2007).

Available at: https://researchrepository.wvu.edu/wvlr/vol110/iss1/23

This Symposium: The Religion Clauses in the 21st Century is brought to you for free and open access by the WVU College of Law at The Research Repository @ WVU. It has been accepted for inclusion in West Virginia Law Review by an authorized editor of The Research Repository @ WVU. For more information, please contact ian.harmon@mail.wvu.edu. 


\title{
IS PUBLIC REASON COUNTERPRODUCTIVE?
}

\author{
Eduardo M. Peñalver
}

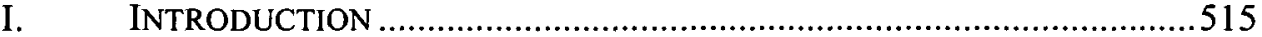

II. A BRIEF OVERVIEW OF THE PUBLIC REASON DEBATE …................517

A. Reasons for Restraint .............................................518

1. Legitimacy ...................................................5 518

$2 . \quad$ Stability ........................................................520

B. Varieties of Restraint ..................................................5 521

C. Objections to Public Reason .............................................5523

III. TWO STORIES ABOUT DIVERSITY AND STABILITY .........................526

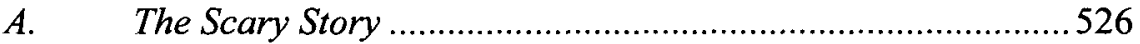

B. The Happy Story ........................................................... 528

IV. How PUBLIC REASON MIGHT FOSTER THE SCARY STORY .................532

A. Public Reason's Narrowing of the Public Conversation........ 533

$B$. The Deliberative Consequences of Public Reason's

Exclusions......................................................................5 536

1. Deliberative Inhibition .......................................536

2. Deliberative Distortion ...................................538

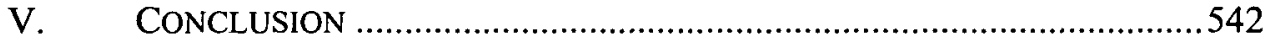

\section{INTRODUCTION}

Over the past two decades, the debate over the proper role of religion within public discourse has become a staple of legal and political theory. $\mathrm{Nu}-$ merous books, ${ }^{2}$ conference panels, ${ }^{3}$ and symposia ${ }^{4}$ have dissected the issue. The

\footnotetext{
1 Associate Professor of Law, Cornell Law School. Thanks to Michael Perry and Steve Shiffrin for helpful comments and suggestions. Thanks also to the American Constitution Society and the West Virginia University College of Law for sponsoring this conference and for inviting me to participate.

2 See, e.g., Christopher J. Eberle, Religious Conviction in Liberal Politics (2002); Amy GutMann \& DenNis Thompson, Democracy and DisagreEMENT (1996); Kent Greenawalt, Private Consciences and Public Reasons (1995); Michael Perry, Religion in Politics (1997) [hereinafter PERry, POlitics]; Michael PERRY, LOVE AND POWER (1991) [hereinafter PerRy, POWER]; John RaWls, Political Liberalism (1993).

3 See, e.g., Samuel Freeman, Public Reason and Political Justifications, 72 FORdHAM L. Rev. 2021 (2004) (panel discussion on public reason at a conference on John Rawls).

$4 \quad$ See, e.g., Symposium, The Role of Religion in Public Debate in a Liberal Society, 30 SAN DEIGO L. REV. 643 (1993) (on the role of religion in political discourse).
} 
discussion has even spilled over into popular commentary (particularly in recent years) in response to the increased power of the Religious Right within the Republican Party and President George W. Bush's conspicuous religiosity. Although they disagree over the precise details, proponents of public reason broadly agree that considerations of fairness and social stability counsel in favor of at least some constraint of religious argument in the public square. ${ }^{5}$

Many critics of the idea of public reason have tended to focus on the fairness of restraining public religious arguments. ${ }^{6}$ Others have pointed to the difficulty of distinguishing between public and non-public reasons and of specifying the scope of activities from which non-public reasons are to be excluded. ${ }^{7}$ Finally, a number of critics have focused on the role of stability within the public reason debate, arguing that religious differences are not an especially grave threat to political stability. ${ }^{8}$

I am sympathetic with each of these criticisms. My narrow focus in this essay, however, will be on the contested relationship between pluralism and stability within the public reason debate. While I agree with those who have questioned the degree to which-in our present circumstances-religious diversity constitutes an especially grave threat to stability, I will go one step farther and argue that it is possible that efforts to exclude religious argument through restrictive theories of public reason may well constitute the greater threat to stability over the long run.

In Part II, to situate my discussion, I will provide a very brief overview of the public reason debate and the menu of positions that different theorists have adopted on the question. Readers who are already familiar with the literature in this area should skip directly to part III, in which I explore at greater length two divergent stories about the relationship between pluralism and stability: one scary and the other happy. The "scary story," which dominates discussions of public reason, treats pluralism as a threat to stability that must be

5 For the most part, discussions of public reason involve discussions of self-restraint in the use of religious argumentation, rather than restraints imposed by law. See GrEENAWALT, supra note 2 , at 4 . When theorists discuss religious argument by government officials, however, they often blend discussions of public reason and the Establishment Clause in a way that lends the force of law to at least some of the restraint of public reason. See, e.g., Abner S. Greene, Constitutional Reductionism, Rawls, and the Religion Clauses, 72 FordHAM L. REV. 2089, 2095-96 (2004).

6 See, e.g., StEPHEN L. CARTER, THE CUltURE Of Disbelief ch. 11 (1994); Eberle, supra note 2, at 17, 140-48; Jurgen Habermas, Religion in the Public Sphere, 14 EUR. J. PHL. 1, 8-9 (2006); David M. Smolin, Regulating Religious and Cultural Conflict in Postmodern America: A Response to Professor Perry, 76 Iowa L. REv. 1067, 1077-79 (1991).

E.g., Perry, Politics, supra note 2, at 47; see also David Hollenbach, The Global Face OF PUBLIC FAITH 170 (2003). Perry makes a similarly pragmatic, but distinct, argument when he observes that the principles that satisfy the demands of some of the more demanding accounts of public reason may not be sufficiently determinate to resolve the important debates in which they are deployed. See PERRY, POLITICS, supra note 2, at 57.

8 See, e.g., EBerle, supra note 2, at ch. 6; HollenbaCH, supra note 7, at 160-65; PERRY, PoLITICS, supra note 2 , at 53 n.37 (collecting sources). 
tamed. In contrast, there has long existed within political theory a more "happy story" according to which pluralism affirmatively contributes to stability by creating incentives for groups to moderate their demands.

These stories are not, at least as a conceptual matter, mutually exclusive. Indeed, it is likely that both are operating to a certain extent within our society. ${ }^{9}$ For my purposes, however, the stories should be understood as competing with one another to serve as-ultimately-the more apt description of the relationship between pluralism and stability. Thus, in Part IV, I argue that, given the importance of stability to the case for public reason, the question of which story is in fact more salient should be central to the discussion of public reason.

Despite its apparent relevance, however, much of the debate over the proper role of religious discourse in public life has proceeded without reference to this important-and ultimately empirical-question. But if the happy story proves to be a more accurate description of our reality, restricting public resort to religious and deep moral reasons may actually backfire. If pluralism, on balance, increases stability and improves the quality of public discourse, restricting its expression might cause the very instability and deliberative harm that proponents of public reason hope to avoid. For those proponents of self-restraint who are focused almost exclusively on the fairness of religious arguments or the legitimacy of government actions whose advocates resort to religious reasons, these potentially harmful consequences of self-restraint in public deliberation will be simply a necessary cost of doing the right thing. But for theorists for whom the consequences of restrictive public reason are an important part of its appeal the account I offer should at least provide a reason to pause and reconsider the value they attach to self-restraint for religious participants in the public conversation.

\section{A BRIEF OVERVIEW OF THE PUBlic REASON DEBATE}

In light of the sheer volume of scholarship addressing the question of public reason, it is virtually impossible to comprehensively describe the range of positions theorists have staked out on the issue. I will therefore limit myself to recounting the broad contours of the debate, paying particular attention to John Rawls's extremely influential theory of public reason. The discussion will of necessity be cursory and not capable of conveying the full sophistication of the views to which I will refer, but it should provide readers unfamiliar with the vast public reason literature with enough of the lay of the land to make sense of the argument I set out in Parts III and IV. In this Part, after discussing the reasons scholars have given for limiting the sorts of arguments that ought to be deployed in public discourse, I will describe the range of positions they have endorsed along four axes of disagreement. I will then briefly discuss the objections that

9 See generally SCOTT PAGE, THE DifFERENCE 255 (2007) (describing normative diversity as having negative "direct" effects and positive "indirect" effects but suggesting agnosticism about which effects predominate). 
commentators have raised against restricting the use of religious arguments in the public square.

\section{A. Reasons for Restraint}

Arguments for restraining public reason typically emphasize two broad themes: (1) liberal conceptions of fairness and legitimacy and (2) the threat of social instability within a pluralist society. ${ }^{10}$ Although they are not always equally emphasized, these two interests often function as interlocking parts of a single argument. Rawls, for example, viewed his discussion of the two questions as deeply interdependent. In Political Liberalism, he describes his argument as proceeding in two steps: first, he provides a preliminary account of public reason within a well-ordered society and, second, he explains how such a just society could actually sustain itself. ${ }^{11}$ While legitimacy and stability can be understood as common elements of a single argument for public reason, it is useful to distinguish between them for the purposes of this paper, both because they are conceptually distinct and because my discussion in the Parts III and IV will be narrowly centered on the question of public reason's complex relationship with stability. ${ }^{12}$

\section{Legitimacy}

The discussion of fairness as a reason for limiting the content of public discourse focuses on the legitimacy of coercive state regulation within a pluralist society. Proponents of public reason rely on the proposition that, in order to justifiably limit individual freedom, the state must act only on the basis of reasons that each citizen could reasonably be expected to accept as his own. ${ }^{13} \mathrm{Lib}$ -

10 See RAWLS, supra note 2, at 133-34 (discussing the importance of both legitimacy and stability in his theory of political liberalism); EBERLE, supra note 2, at 152; John Rawls, The Idea of an Overlapping Consensus, 7 OXFORD J. LEGAL STUD. 1, 10 (1987) [hereinafter Rawls, Overlapping Consensus]; John Rawls, The Idea of Public Reason Revisited, 64 U. CHI. L. REV. 765, 77071 (1997) [hereinafter Rawls, Public Reason]; see also Ed Wingenbach, Unjust Context: The Priority of Stability in Rawls's Contextualized Theory of Justice, 43 AM. J. POL. SCI. 213, 220-21 (1999) (arguing that under Rawls's Political Liberalism theory "[i]nsuring cooperation and stability becomes the first and only goal of the political conception of justice; social division and possibly war define the alternative.").

11 See RAwLS, supra note 2, at 140-41.

12 I do not mean this focus on stability to imply that it is my only concern with restrictive accounts of public reason. For example, I share the views of many of those who have objected to public reason on fairness grounds. See infra Part II.C. But, as I discuss below, the relationship between public reason and stability has, in my view, not been sufficiently explored within the existing public reason literature.

13 GUTMANN \& THOMPSON, supra note 2, at 13-14; see also RaWLs, supra note 2, at 217 ("[O]ur exercise of political power is proper and hence justifiable only when it is exercised in accordance with a constitution the essentials of which all citizens may reasonably be expected to endorse in light of principles and ideals acceptable to them as reasonable and rational."); Bruce 
eral theorists understand this conception of legitimacy as an essential component of their commitment to a political community that regards citizens as "free and equal."14 Amy Gutmann and Dennis Thompson, for example, argue that the demand that political decisions should be "justifiable, as far as possible, to everyone bound by them" uniquely expresses the reciprocity appropriate when we "respect one another as moral agents." 15 Similarly, Thomas Nagel at one time argued that political liberalism's commitment to equality among citizens requires that governmental restraints on action be justifiable from some "impersonal standpoint" and not just from within a citizen's own particular conception of the good. ${ }^{16}$

Because modern societies are free, these theorists posit, societies are characterized by deep, ineradicable-and ultimately reasonable-disagreement about conceptions of the good. ${ }^{17}$ Proponents of public reason refer to this phenomenon as the "fact of reasonable pluralism." Combining this inescapable and reasonable moral and religious disagreement with a view of legitimacy that prohibits coercion on grounds that a citizen might reasonably reject yields a principle of restraint (the precise contours of which are subject to substantial disagreement) limiting the sorts of reasons that can be offered in support of state action restricting individual freedom to reasons that are not excluded by any of the numerous reasonable conceptions of the good that a citizen might hold. ${ }^{19}$

Ackerman, Why Dialogue?, 86 J. PHIL. 5, $17-18$ (1989); Robert Audi, The Place of Religious Argument in a Free and Democratic Society, 30 San DiEGo L. REv. 677, 688-89 (1993); Gerald F. Gaus, The Place of Religious Belief in Public Reason Liberalism, unpublished manuscript on file with author, at 3; Stephen Macedo, In Defense of Liberal Public Reason, in NATURAL LAW AND Public Reason 11, 35 (Robert P. George \& Christopher Wolfe eds., 2000); Rawls, Public Reason, supra note 10, at 771; Lawrence B. Solum, Public Legal Reason, 92 VA. L. REV. 1449, 1469 (2006).

14 See Rawls, Public Reason, supra note 10, at 770 ("Citizens are reasonable when, viewing one another as free and equal in a system of social cooperation over generations, they are prepared to offer one another fair terms of cooperation according to what they consider the most reasonable conception of political justice; and when they agree to act on those terms, even at the cost of their own interest in particular situations, provided that other citizens also accept those terms."); see also Lawrence B. Solum, Constructing an Ideal of Public Reason, 30 SAN DIEGo L. REv. 729, 733-34 (1993).

15 GuTMANn \& ThOMPson, supra note 2, at 13-14.

16 See Thomas Nagel, Moral Conflict and Political Legitimacy, 16 PHIL. \& PuB. Afr. 215, 229-31 (1987). However, because of objections to Nagel's position raised by Joseph Raz in his article, Facing Diversity: The Case of Epistemic Abstinence, 19 PHIL. \& PUB. AfF. 3 (1990), Nagel has since abandoned the position he staked out in Moral Conflict and Political Legitimacy. GREENAWALT, supra note 2, at 73-74.

17 See RAwLs, supra note 2, at 36-40; Rawls, Overlapping Consensus, supra note 10, at 3.

18 See RAWLs, supra note 2, at 144; see also GUTMANN \& THOMPSON, supra note 2, at 26.

19 See RAWLS, supra note 2, at 58-66. 


\section{Stability}

Although the liberal requirements for legitimacy typically receive more attention than questions of stability, I agree with Steven H. Shiffrin that, for many theorists of public reason, "what is really driving the [public reason] doctrine . . . is fear about the instability effects of religion." 20 As with legitimacy, discussions of stability within arguments for restrictive public reason begin with the fact of reasonable pluralism regarding values and conceptions of the good. But the concern with stability quickly guides theorists in a direction that is far more empirical and pragmatic in its orientation than the discussions of legitimacy. The aim of liberal political philosophy, perceived through the lens of stability, is not solely the articulation of a theoretically just social order, but also the more "practical political goal" of "secur[ing] stability and social unity.", It seeks to answer the question: "How is it possible that there may exist over time a stable and just society of free and equal citizens profoundly divided by reasonable though incompatible religious, philosophical, and moral doctrines?",22 From this view, then, "the problem of stability is fundamental to political philosophy ...."23

The argument that concern for stability counsels in favor of a restrictive account of public reason typically presupposes that it is by some shared moral commitment-however thin-that pluralist democracies can best ensure their survival as going concerns. ${ }^{24}$ To that end, theorists of public reason often search for an "overlapping consensus," or a shared conception of the fair rules of the road on which people can converge within their varying comprehensive conceptions of the good. ${ }^{25}$ They conceive of this overlapping consensus as involving a commitment to limit the sphere of permissible government conduct and prohibiting the state's enforcement of one particular conception of the good or system of values over others.

It is in evaluating this consensus with an eye toward the goal of fostering stability that theorists distinguish between a true overlapping consen-

20 Steven H. Shiffrin, Religion and Progressive Politics 24 (unpublished manuscript). For a very thorough discussion of similar arguments within the Supreme Court's First Amendment jurisprudence, see Richard W. Garnett, Religion, Division, and the First Amendment, 94 Geo. L.J. 1667 (2006).

21 John Rawls, Justice as Fairness: Political, Not Metaphysical, 14 PHIL. \& PUB. AfF. 223, 225 (1985).

22 RAWLS, supra note 2 , at xviii.

23 Id. at xvii.

24 See Rawls, Overlapping Consensus, supra note 10, at 1 (observing that a crucial aim of political philosophy is to present a political conception of justice that can provide a "shared public basis for the justification of political and social institutions," thereby helping to "ensure stability from one generation to the next."); Shiffrin, supra note 20 , at 23; Wingenbach, supra note 10, at 224 ("For [Rawls], the lack of any common doctrine leads to political conflict and disorder, and, therefore, the need arises to impose a common but nonmetaphysical doctrine to ensure stability.").

See, e.g., RAWLS, supra note 2 , at xviii-xix. 
sus-that is, a shared, albeit thin, conception of political justice-and a "mere modus vivendi." 26 The former involves a principled commitment by adherents of different moral conceptions to uphold the values embodied in the overlapping consensus, and is therefore very effective (or so the argument goes) at ensuring the requisite stability. ${ }^{27}$ The latter is inherently unstable-and therefore inferior-because it is not rooted in any shared principles. As a consequence, it is not affirmed for its own sake, but only as a prudential accommodation to practical necessity that can break down at any moment if the balance of power shifts. $^{28}$

The notion of public reason enters as a crucial contributor to the stability generated by a true overlapping consensus. An obligation to abide by the limitations of public reason in political debate is an expression of citizens' duty to treat each other with respect, one whose exercise reinforces the overlapping consensus and the social stability that it engenders. ${ }^{29}$ By bracketing deep moral disagreement, public reason fosters stability by minimizing the possibility that political debate will devolve into heated confrontation, and possibly violence. Because of the importance of the overlapping consensus and of public reason to stability, groups that reject them constitute dangerous threats to that social order. As such, they must be contained "like war and disease."

\section{B. Varieties of Restraint}

Theorists have deployed these discussions of legitimacy and stability in support of a broad range of substantive conceptions of public reason. A detailed account of the numerous specific theories that have made their appearance in this decades long (and still ongoing) debate would take far longer, and be more tedious, than most readers would be willing to tolerate. Accordingly, I will limit myself to a cursory recitation of the range of views that have been proposed. In doing so, I will focus on four axes of disagreement: (1) the content to be excluded (or required); (2) the actors who are to be bound by the restraints; ( 3 ) the contexts in which the restraints are to apply; and (4) the nature of the restraints, that is, whether the restraints should be understood as exclusive or inclusive.

In setting forth the content of discourse permitted by their particular theories of public reason, scholars have run the gamut. At the least restrictive end of the spectrum, they have focused narrowly on the perceived dangers of the specific category of reasons associated with religious belief. Robert Audi, for example, limits his conception of the content excluded by public reason to what

See RAWLS, supra note 2, at 144-50.

See Rawls, Public Reason, supra note 10, at 780; Rawls, Overlapping Consensus, supra note 10 , at 10 .

28 See Raz, supra note 16 , at 13.

See RAWLS, supra note 2, at 217.

Id. at 64 n. 19 . 
he calls "religious reasons," requiring that participants in public discourse offer only reasons that are secular in nature. ${ }^{31}$ A similar, though perhaps broader, conception of the content excluded by public reason restricts the use of so-called "nonaccessible" reasons. 32 Finally, and most broadly, theorists like Rawls and Lawrence Solum would exclude a far greater number of reasons, namely all those too closely tied to "controversial" (or "comprehensive" or some other such term) conceptions of the good. ${ }^{33}$ In Rawls's formulation of this standard, with which Solum largely agrees, public reason should be narrowly limited to those reasons endorsed by "common sense" and "the procedures and conclusions of science when these are not controversial.",34

It is worth noting that, even within broader accounts of the reasons excluded by the requirement of publicity, the question of the proper role of religion within public discourse stands at the foreground. This is because, under any of the formulations of public reason, even those as all-encompassing as John Rawls's, religious discourse qualifies as the nonpublic reason par excellence. In other words, despite theorists' disagreements about the precise contours of public reason, they are unanimous in believing that, if anything is to count as nonpublic in the relevant sense, religious reasons will fit the bill. ${ }^{35}$

Public reason's champions are also divided over who exactly should be restrained by their theories. Some, such as Rawls in later versions of his position, would impose the limits of public reason primarily on government actors, or on some subset of state actors in their official capacities. ${ }^{36}$ Others would extend the requirements of public reason to normal citizens, at least under certain circumstances. ${ }^{37}$

As with the question of how to describe the sorts of arguments to be excluded, scholars differ over the precise contexts in which the restraints of public reason should apply. On the less restrictive end of this spectrum is Rawls, who would limit the restrictions to debates and decisions concerning "constitutional

31 Robert Audi, The Separation of Church and State and the Obligations of Citizenship, 18 PHIL. \& PUB. AfF. 259, 278 (1989). Indeed, Audi goes even farther and would restrict religious motives from public decision-making. Id. at 284.

32 See, e.g., GREENAWALT, supra note 2, at $72-78$ (describing but not endorsing a view that public reasons should be accessible from an impartial standpoint). It is actually difficult to say whether this way of conceiving of the restraints imposed by public reason is narrower or broader than the exclusion of "religious" reasons, because-as Kent Greenawalt has observed-it is arguably the case that at least some religious reasons are "accessible" and that at least some nonreligious reasons are inaccessible in the relevant sense. See id. at 39-40.

33 See Rawls, Overlapping Consensus, supra note 10, at 8, 14; Solum, supra note 13, at 1468.

34 See Rawls, Overlapping Consensus, supra note 10, at 8; Solum, supra note 13, at 1468.

35 See EBERLE, supra note 2, at 12 (noting that, despite their disagreement on any number of issues, proponents of public reason are unanimous in identifying religious reasons as quintessentially nonpublic).

36 See, e.g., Rawls, Public Reason, supra note 10, at 767-69; see also GREENAWALT, supra note 2 , at $158-60$.

37 See, e.g., Audi, supra note 31, at 278-89. 
essential[s] and matter[s] of basic justice." 38 Others would impose the restrictions on virtually any form of political activity, including private citizens's normal voting decisions, thereby restraining the use of nonpublic reason in relation to virtually all political conduct apart from political discussions within private associations. ${ }^{39}$

Finally, some theorists would require that, in situations in which the restraints of public reason apply, actors employ public reasons exclusively of nonpublic reasons. This appears to have been the view of Rawls in his earlier thinking on the matter, ${ }^{40}$ although he ultimately changed his position. ${ }^{41}$ Alternatively, following Lawrence Solum (and the later Rawls), one can conceive of the requirement of public reason as inclusive, requiring only that, at a minimum, speakers include public reasons among the reasons they offer. ${ }^{42}$

The number of variables at play in discussions of public reason makes it possible for theorists to formulate an almost countless number of positions on the issue. One can, like Audi, combine a narrow conception of the reasons excluded by the requirements of public reasonableness with a broad understanding of who must comply with those requirements, and under what circumstances. Alternatively, one can, like Rawls, adopt a broad conception of the reasons excluded and yet accept a narrower range of situations in which the exclusion will operate. The possibilities are virtually endless. And yet all of these positions rely on the same basic intuitions about legitimacy and stability and so are susceptible-admittedly to varying degrees-to the same broad set of critiques.

\section{Objections to Public Reason}

Most of the criticism of public reason has focused around three broad themes. First, the sheer variety of theories, and the vagueness of some of the key terms on which they rely, have led some scholars to question the practicality or utility of the entire exercise. John Finnis and others, for example, have criticized Rawls's account of public reason as riddled with "ambiguities so irresoluable as to amount to incoherence."43 Michael Perry has likewise argued that

\footnotetext{
38 Rawls, Public Reason, supra note 10, at 770.

39 See, e.g., Audi, supra note 31, at 278-89; GUTMANN \& THOMPSON, supra note 2, at 52.

$40 \quad$ See RAWLS, supra note 2, at 247 n.36.

41 Rawls, Public Reason, supra note 10 , at 776.

42 See Solum, supra note 13, at 1470.

43 John Finnis, On 'Public Reason' 3-4 (Notre Dame Legal Studies Paper No. 06-37, Apr. 2006), available at http://ssrn.com/abstract=955815. Finnis focuses in particular on the difficulty of understanding what Rawls and other proponents of public reason mean when they talk about reasons that all reasonable citizens "may reasonably be expected to endorse." Id. at 4 . As Finnis correctly observes, "expected" in this context can either be descriptive or normative. If the standard is normative (What arguments ought reasonable people endorse?), then it presupposes some higher standard of truth or reasonableness by which to assess the publicity of an argument, and seems to render the overlapping consensus irrelevant. But if it is merely predictive (What arguments will reasonable people in fact endorse?), then it seems unacceptably arbitrary and contin-
} 
trying to exclude religious argument from public debate would be an attempt to "do the impossible." 44 In a similarly pragmatic vein, Steve Shiffrin has observed that, since the norms of public reason are understood by their proponents to operate at the level of political morality (as opposed to legal prohibition), and since the arguments on behalf of public reason are likely to be convincing primarily to progressive religious believers, theories of public reasonableness would have the effect of working a unilateral disarmament and therefore an undesirable ideological distortion within the marketplace of ideas. ${ }^{45}$

A second, and more conceptual, line of attack has been to question the claims of fairness made on behalf of public reason. This criticism actually comes in two flavors. First, scholars have argued that the notion of legitimacy underlying the call for the restraints of public reason is far too demanding. Against the view that the requirements of public reason are necessitated by a respect for the equal status of citizens, these critics argue that it would not impermissibly fail to treat people equally to adopt some less demanding standard, such as, for example, "a principle that the greater number would prevail in their judgments, even when their judgments include nonaccessible grounds." Alternatively, they say, we might conclude that fairness only requires that we allow "differing comprehensive views to compete in democratic politics.",47 Indeed (they conclude), to assume, as do a number of proponents of restrictive public reason, that fairness requires that one not be coerced except on grounds that she could reasonably accept as her own is simply to assert at the outset that society must be structured according to liberal political principles, a claim that nonliberal theorists predictably reject. ${ }^{48}$

This last point leads directly to the second flavor of fairness argument levied against public reason's proponents: that the requirement of public reason

gent. See id.; see also Robert P. George \& Christopher Wolfe, Natural Law and Public Reason, in Natural Law and Public Reason 51, 52-55 (Robert P. George \& Christopher Wolfe eds., 2000).

44 See Perry, Politics, supra note 2, at 47; see also HollendaCh, supra note 7, at 170 . Perry makes a similarly pragmatic, but distinct, argument when he observes that the principles that satisfy the demands of some of the more demanding accounts of public reason may not be sufficiently determinate to resolve the important debates in which they are deployed. PERRY, POLITICS, supra note 2 , at 57 .

45 See Shiffrin, supra note 20 , at 26 n. 115.

46 GreEnawalt, supra note 2, at 77.

47 Steven Shiffrin, Religion and Democracy, 74 Notre Dame L. REv. 1631, 1638 (1999). See also EBerLe, supra note 2, at ch. 5; Michael J. Perry, Religious Morality and Public Choice, 30 SAN DIEGO L. REv. 703, 714 (1993) ("Political choices that cannot be defended without relying on religious beliefs do not invariably deny to those who reject (or 'reasonably' reject) the beliefs the respect due them as fellow citizens, as 'free and equal' persons, or simply as human beings."); PERRY, POLITICS, supra note 2, at 51, 59.

48 See Michael J. Sandel, Political Liberalism, 107 Harv. L. REv. 1765, 1777-82 (1994); see also PERRY, POLITICS, supra note 2, at 59; Larry Alexander, Liberalism, Religion, and the Unity of Epistemology, 30 SAN DIEGo L. REv. 763, 767 (1993). 
is not in fact neutral among conceptions of the good and therefore works its own form of unfairness. ${ }^{49}$ Audi's account of public reason, to take the most egregious example, would exclude virtually all (and only) religious arguments, thereby favoring secular conceptions of the good as well as those religious conceptions that view secular philosophy as an independent path to truth. ${ }^{50}$ But more even-handed accounts of public reason are also susceptible to this attack. Responding to the fairly permissive account of public reason that Michael Perry set out in his book Love and Power, for example, David Smolin argued that Perry's openness to public religious argumentation-so long as it values diversity and is open to revision-unfairly disfavors the political activity of evangelical Christians and other religious traditionalists. ${ }^{51}$

The third theme voiced by critics of restrictive accounts of public reason has been to question the degree to which a permissive attitude toward the content of political argumentation would, in fact, destabilize our pluralist democracy. Scholars making these arguments have often pointed to the great distance between our society and the wars of religion in sixteenth century Europe. ${ }^{52}$ David Hollenbach, for example, has challenged the notion that, within contemporary society, discourse about religious views is necessarily uncivil or unproductive or will inevitably lead to conflict, as proponents of public reason often seem to assume. ${ }^{53}$

I am sympathetic with all of these arguments, but I will explore in this essay a somewhat different facet of the stability question. Instead of merely defending religious discourse against accusations that it is destabilizing, it is possible, as some theorists have already begun to do, to develop a radically different story about the relationship between pluralism and stability than the one on which Rawls, and many other proponents of restrictive public reason, implicitly rely. It is to these two divergent stories of the relationship between diversity and stability that I turn in the next Part. Once I have set them out, I will explain how applying within one story a theory of public reason that is more appropriate than the other can help bring about the very instability that theories of public reason hope to avoid.

\footnotetext{
49 See CARTER, supra note 6, at ch. 11; EBERLE, supra note 2, at 17, 140-48; Habermas, supra note 6, at 8-9; Smolin, supra note 6, at 1077-79.

50 See Lawrence B. Solum, Pluralism and Public Legal Reason, 15 WM. \& MARY BILL RTS. J. 7,11 (2006).

51 See Smolin, supra note 6, at 1077-79. In response to Smolin's objections, Perry has modified his views and now favors a more inclusive position toward religious argument in political discourse. See Michael J. Perry, Religious Morality and Public Choice, 30 SAn Diego L. Rev. 703, 713 (1993). In a similar vein, Kent Greenawalt has observed that most accounts of public reason would permit secular speakers to employ their comprehensive conceptions of the good to a greater degree than would religious speakers. See GrEENAWALT, supra note 2, at 83.

52 See, e.g., PERRY, POLITICS, supra note 2, at 53 n.37 (collecting sources).

53 HollenBACH, supra note 7, at 160-65.
} 


\section{Two STORIES ABOUT DIVERSITY AND STABILITY}

Scholars usually tell one of two stories when they talk about the relationship between stability and the values of pluralism characteristic of modern society. The first story, and the dominant one within discussions of public reason, is a "scary" story in which pluralism constitutes a grave threat to stability that must be tamed. The second, and less common story, is one in which the relationship between pluralism and stability is portrayed far more optimistically, with pluralism affirmatively contributing to stability.

\section{A. The Scary Story}

The more familiar of the two stories about pluralism and diversity is the scary one. This story actually consists of two subplots, one concerned with pluralism's impact on the quality of public deliberation and the second focused on its tendency to directly undermine social peace. These two subplots are part of the same story because the deterioration of public discourse will likely push society toward acrimony and instability, but the mechanisms of the two are sufficiently distinct that they are worth discussing separately.

The first subplot, which attributes to pluralism a negative impact on the quality of public discourse, is implicitly linked, as Jeremy Waldron has noted, to an Aristotelian conception of deliberation, within which shared modes of reasoning are essential to deliberative success. ${ }^{54}$ Viewed from within this framework, pluralism appears as an unalloyed threat to a society's ability to deliberate because it undermines the necessary common ground on which to base a successful public conversation. Obviously, no particular comprehensive conception of the good can provide this common discursive bedrock, because, by assumption, the fact of pluralism prevents any one conception from gaining sufficient traction except through the (impermissible) use of coercion. ${ }^{55}$

This is not to say that proponents of the scary story understand pluralism as bad or harmful in itself. To the contrary, they attribute positive meaning to the observed diversity of beliefs about value within modern society, which they see as flowing from (and therefore indicative of) respect for freedom of conscience. ${ }^{56}$ At the same time, however, they tend to approach pluralism with

\footnotetext{
54 See Jeremy Waldron, Religious Contributions in Public Deliberation, 30 SAN DIEGo L. REv. 817, 835-36 (1993).

55 See Rawls, Overlapping Consensus, supra note 10, at 4.

56 See, e.g., RAWLS, supra note 2, at xxiv ("[P]luralism is not seen as disaster but rather as the natural outcome of the activities of human reason under enduring free institutions."); Solum, supra note 13, at 1469.
} 
some ambivalence because, while it is characteristic of a well ordered society, it also constitutes a looming threat to social harmony. ${ }^{57}$

On this view, arguments tied too closely to a comprehensive conception of the good, and especially to religious conceptions, are dangerous to the quality of public deliberation because they have the tendency to give offense and to inhibit discussion. "The main reason religion needs to be privatized," Richard Rorty argues, "is that, in political discussion with those outside the relevant religious community, it is a conversation-stopper." 58 By ending conversations prematurely, religious argument degrades the quality of public deliberation.

Drawing heavily on the sixteenth-century European wars of religion as a trope in order to illustrate the risks flowing from pluralism, the second subplot of the scary story focuses on the role of pluralism as a more direct threat to civility in public life. ${ }^{59}$ The risk is always present that people committed to a particular conception of the good will seek to employ the coercive power of the state to advance their cause or will simply break out into open conflict with those committed to a different set of beliefs. Unless this potential for conflict is constrained by some common moral commitment to coexist that is itself sufficiently robust and entrenched, the argument goes, pluralist societies will labor under the constant threat that adherents of competing conceptions will turn on each other, causing society either to splinter into pieces or to descend into civil war. Christopher L. Eberle helpfully dubs these warnings of civil war and social disintegration, respectively, the "argument from Bosnia" and the "argument from divisiveness." 60

It is true that proponents of a particular conception of the good will often have difficulty amassing the power necessary to defeat their rivals. Under these circumstances, they may abide by temporary cease-fire, living in relative peace, each hoping for a time when they can gain enough power to impose their own viewpoint. But, Rawls asserts, this is merely a modus vivendi and is therefore inherently unstable, not a sound basis on which to build lasting social peace. $^{61}$

The project for those operating within both subplots of the scary story is to find some common set of beliefs around which enough people within a modern, pluralist society can come together. Within Rawls's thought, this unifying role is served by the "overlapping consensus," which takes the form of a shared commitment to limited government that secures the (private) moral space within which different communities can peacefully deliberate and coexist. ${ }^{62}$ As I've

57 See Wingenbach, supra note 10, at 224 ("For [Rawls], the lack of any common doctrine leads to political conflict and disorder, and, therefore, the need arises to impose a common but nometaphysical doctrine to ensure stability."); Shiffrin, supra note 20, at 24.

58 Richard RoRTY, PHILOSOPHY AND SOCIAL HOPE 171 (1999).

59 See EBERLE, supra note 2, at 154-55 (collecting sources).

$60 \quad$ Id. at ch. 6.

61 RAWLS, supra note 2, at 140.

62 See Rawls, Public Reason, supra note 10, at 773-74. 
already related, a crucial part of this overlapping consensus is a commitment to employ public reason when discussing important political questions. ${ }^{63}$ The commitment to public reason flows from a desire to avoid the socially disintegrative impact of deep moral, and especially religious, argument on public political discourse. ${ }^{64}$ Theorists view these sorts of arguments as intrinsically uncivil and prone to devolve into outright hostility or violence. Society mitigates that risk by restricting them to the private sphere. By bypassing comprehensive doctrines, Rawls. explains, "we try to bypass religion and philosophy's profoundest controversies so as to have some hope of uncovering a basis of a stable overlapping consensus." ${ }^{65}$

\section{B. The Happy Story}

Far less visible within the debate over public reason, but no less venerable within political theory as a whole, is a more optimistic story about the relationship between pluralism and stability. This alternative narrative treats pluralism as affirmatively fostering, rather than inevitably undermining, deliberation and stability. Far from constituting a threat to be cabined, pluralism-on this view-contributes positively to the quality of public deliberation and, somewhat paradoxically, becomes part of the glue that holds society together.

The prelude to the happy story is to cast doubt on the claim that deep moral and religious argument within our pluralist society is especially likely to lead to instability and violence. As a general matter, Joseph Raz has correctly observed that it is not clear that social stability depends on shared modes of moral reasoning and deliberation as much as on the effectiveness of less rational symbolic and cultural commitments that bind national communities together. ${ }^{66}$ And, as numerous commentators have observed, religious argumentation is

\footnotetext{
63 See supra notes 24-30 and accompanying text.

64 See supra note 57.

65 Rawls, Overlapping Consensus, supra note 10, at 14. It is for a similar reason that, in discussing his version of public reason, Solum expresses his concern that his willingness to permit religious and other nonpublic reasons into the public debate (so long as they are accompanied by adequately public reasons) will undermine social stability. "Even if the...nonpublic reasons are limited to a supporting role for public reasons," he says, "allowing them at all risks undermining the value of civility. After all, the fact that a religious reason is given at all may be offensive to some." Solum, supra note 14, at 749. Although Solum ultimately views the benefits of permitting nonpublic reasons to outweigh the costs of excluding them, his concern about their possibly corrosive impact on civility bears the fingerprints of the scary story. See id. at 748-52. Of course, that he engages in balancing at all means that Solum understands that the restriction of religious reasons entails certain deliberative costs. In other words, his argument implicitly relies on intuitions very similar to those underlying my argument in Part IV. In the final analysis, however, Solum does not fully acknowledge the possible questions those costs raise for the particular theory of public reason he favors.
}

66 Raz, supra note 16, at 30-31 ("Symbolic and affective identification and a partial cognitive overlap may be a very firm foundation for social unity and stability . . .."). 
widespread in our public discourse, as it has been throughout our history, and yet there are no signs of an impending descent into religious warfare. ${ }^{67}$

Like the scary story, the happy story can be disaggregated into two subplots. In the first, theorists discuss the effect of pluralism on the quality of the outcomes produced by public deliberation. In the second, they focus on the directly salutary effect of pluralism on political stability.

Waldron points toward the first part of this happy story in his discussion of Mill's conception of the marketplace of ideas. ${ }^{68}$ He is correct that John Stuart Mill's vision of deliberation attributes affirmative value to pluralism in a way that puts it fundamentally at odds with the scary story. For Mill:

Truth, in the great practical concerns of life, is so much a question of the reconciling and combining of opposites, that very few have minds sufficiently capacious and impartial to make the adjustment with an approach to correctness, and it has to be made by the rough process of a struggle between combatants fighting under hostile banners. ${ }^{69}$

As Waldron observes, "[f]or Mill's model to work, it is less important that the competing ideas be intellectually commensurable," and so the question of regulating the content of public discussions for consistency with an ideal of public reasonableness never really arises. ${ }^{70}$

Waldron describes this Millian conception of public discourse as one in which competing factions alternatively fling their ideas at one another. He asks:

Who cares if a specifically biblical doctrine is flung up against the secular views of, say, a Robert Nozick or a P.J. O'Rourke? The ideas will have their effect on one another, and something better will (or may) emerge in the clash, even though the "adjustment" between the two views has not been made by any "single mind."71

I agree with Waldron that, so described, Mill's model is not an especially attractive one. ${ }^{72}$

But, instead of celebrating the directionless clash of factions or the mindless flinging of ideas, we can emphasize, with Cass R. Sunstein and Scott

\footnotetext{
67 See Shiffrin, supra note 20, at 24-25; Phillip L. Quinn, Political Liberalisms and Their Exclusions of the Religious, 69 Proc. \& Addresses OF THE AM. PHIL. Ass'N 35, 39 (1995).

68 See Waldron, supra note 54, at 836-37.

69 JOHN StUART MiLL, ON LibERTY 47 (Alburey Castell ed., Harlan Davidson, Inc. 1947).

70 Waldron, supra note 54 , at 837.

71 Id.

72 See id.
} 
Page, among others, the value of including a diversity of viewpoints and ideas-even seemingly incommensurable ones-within the deliberative process. $^{73}$ The principal danger to be avoided on this view is not excessive pluralism but rather too constrained a debate, and in particular a debate from which specific points of view are systematically excluded. ${ }^{74}$ Dissenters and out-groups who introduce their ideas into public discourse play a crucial role in restraining established groupthink, prompting discussion where consensus might otherwise be unreflectively assumed. ${ }^{75}$ Within this subplot of the happy story, the aim of deliberation should not be to set artificial limits on the content that will be admitted into the public conversation but instead to cast the net widely, bringing in as many viewpoints as practicable in order to correct for the deliberative blindspots that inevitably result when we speak only with the like-minded.

The second subplot of the happy story focuses on the way in which pluralism directly contributes to political stability. It is perhaps most famously embodied in James Madison's argument in The Federalist No. 10 about the relationship between the stability of republican government and the size and diversity of the political community. ${ }^{76}$ Far from conceiving of pluralism as a threat to be feared, Madison viewed it as an essential ingredient of stability in a free society. Like proponents of the scary story, Madison begins with the fact of pluralism. $^{77}$ The solution he offers, however, is not a unifying overlapping consensus or the pacifying constraints of public reason. Instead, he describes the solution to the fact of pluralism as yet more pluralism, which will make it increasingly difficult for one faction to exert unfettered control over state power:

73 See generally Cass R. Sunstein, The Law of Group Polarization, 10 J. PoL. PHIL. 175 (2002); PAGE, supra note 9, at 285-86; Waldron, supra note 54, at 841-42.

74 See Sunstein, supra note 73 , at $184-85$.

75 Alexander Hamilton discusses the positive role for the seemingly impolite flinging of ideas within legislative debate, which he sees as promoting "deliberation and circumspection" and "check[ing] the excesses of the majority." THE FEDERALIST No. 70 (Alexander Hamilton).

76

77

THE FEDERALIST No. 10 (James Madison).

Id. As Madison put it:

A zeal for different opinions concerning religion, concerning Government and many other points, as well of speculation as of practice; an attachment to different leaders ambitiously contending for pre-eminence and power; or to persons of other descriptions whose fortunes have been interesting to the human passions, have, in turn divided mankind into parties, inflamed them with mutual animosity, and rendered them much more disposed to vex and oppress each other than to co-operate for their common good. So strong is this propensity of mankind to fall into mutual animosities, that where no substantial occasion presents itself, the most frivolous and fanciful distinctions have been sufficient to kindle their unfriendly passions, and excite their most violent conflicts.

Id. 
The smaller the society, the fewer probably will be the distinct parties and interests composing it; the fewer the distinct parties and interests, the more frequently will a majority be found of the same party; and the smaller the number of individuals composing a majority, and the smaller the compass within which they are placed, the more easily will they concert and execute their plans of oppression. Extend the sphere, and you take in a greater variety of parties and interests; you make it less probable that a majority of the whole will have a common motive to invade the rights of other citizens; or if such a common motive exists, it will be more difficult for all who feel it to discover their own strength, and to act in unison with each other. ${ }^{78}$

A number of modern political theorists have followed Madison in affirming that pluralism contributes positively to stability, although they have attributed that positive relationship to a somewhat different mechanism. Madison's discussion in The Federalist No. 10, which focuses on the difficulty of one particular faction gaining sufficient political power to impose its program on the rest of society, takes for granted that each faction will invariably be prone to seek such a totalizing victory. He simply argues that a sufficiently pluralist society will make such victory virtually impossible to achieve. ${ }^{79}$

Modern theorists, however, tend to take a more dynamic approach to the behavior of factions and to argue that being forced to operate within the context of a pluralist political society affirmatively moderates the aspirations of "factions." We can understand this moderating impact as working through at least two different, though by no means mutually exclusive, mechanisms. First, when members of different groups interact in a pluralist political community, they may exert social pressure on each other to moderate their demands. As Nicholas R. Miller has described it, "many interactions [in a pluralist society] must take place across preference clusters and, insofar as preferences are shaped by social pressures, these pressures are operating in somewhat contrary directions, producing less intense and probably less extreme attitudes." 80

Second, the process of coalition formation necessary to cobble together a working majority within a pluralist society creates its own incentives for groups to restrain themselves from acting in ways that will permanently alienate their current adversaries. In a diverse society, "[t]hose who are enemies in one situation are sometimes required to act as allies in another situation. With an eye on future co-operation, they restrain their behavior in present competition." 81

\footnotetext{
$78 \quad$ Id.

79 Id.

80 Nicholas R. Miller, Pluralism and Social Choice, 77 AM. POL. SCI. REv. 734, 736 (1983).

81 Frederick George BaILEy, STRATAGEMS AND SPOILS 129 (1969) (quoted in Miller, supra note 80, at 736.); see also ROBERT A. DAHL, DEMOCRACY IN THE UNITED STATES 300-02 (4th ed.
} 
In other words, the coalition building predicted by Madison in The Federalist No. 10 not only makes it harder for factions to gain power, it may actually foster the very virtues of moderation and pragmatism that reduce the threat posed by faction and thereby help to stabilize a diverse society. ${ }^{82}$ These stabilizing mechanisms do not operate as well when society is divided along just a small number of lines into a handful of groups that do not overlap or need to rely much on each other to exercise political power. Consequently, it may be the case that a less diverse society is at greater risk of instability than one in which radical diversity - and the cooperative political activity it encourages-is a more or less permanent fact of life. As Edward Alsworth Ross put it:

A society ... which is riven by a dozen oppositions along lines running in every direction, may actually be in less danger of being torn with violence or falling to pieces than one split along just one line. For each new cleavage contributes to narrow the cross clefts, so that one might say that society is sewn together by its inner conflicts. ${ }^{83}$

\section{How PUblic REASON Might Foster the SCARy Story}

Whether, at the end of the day, the fact of pluralism undermines society or stabilizes it, whether it actually degrades public discourse or (on balance) improves it, ought to be of central importance to the debate over public reason. This is especially the case in light of theorists' professed interest in fostering stability. And yet the discussion to date has occurred without reference to these empirical questions. ${ }^{84}$ Which of the two competing stories is more salient, however, should make a great deal of difference to the ways in which theorists treat the question of pluralism, including religious pluralism, and its role within public discourse because applying a conception of public reason that would be appropriate within the scary story may actually prove detrimental to that goal if society actually operates more along the lines described within the happy story. If, on balance, pluralism works to affirmatively improve the quality of public discourse and to stabilize society, adopting a conception of public reason that seeks to stifle the full expression of society's pluralism could prove detrimental. It could have the effect of squandering the deliberative benefits of existing diversity in order to buy insurance against a non-existent risk, thereby creating a self-fulfilling prophecy in which the purported cure helps to bring about the very discursive and communal harms that it seeks to forestall.

1981) ("[E]very ally is sometimes an enemy and every enemy is sometimes an ally. Consequently, polarization of politics along ideological lines is held in check.").

82 See The Federalist No. 10 (James Madison).

83 EdWARD Alsworth Ross, THE PRINCIPLES OF SOCIOLOGY 165 (1920) (emphasis in original).

84 See, e.g., Eberle, supra note 2, at 160; PAUL J. WeIthMan, Religion AND THE Obligations OF CITIZENSHIP 39-40 (2002). 
This is a different point than Shiffrin's makes, which I have already discussed above, about public reason leading to unilateral disarmament, ${ }^{85}$ although, the two points are not wholly unrelated, as I will discuss. Shiffrin convincingly argues that, as a practical matter, only religious progressives are likely to find the arguments in favor of public reason sufficiently convincing that they actually restrain their use of religious argument in public discourse. As a consequence, he observes, voluntary movement toward the norm of public reason will inevitably be politically unbalanced, leaving the field of public religious argument to political conservatives. ${ }^{86}$ I would go one step further, however, and assert that, even if the requirements of public reason were honored equally by religious people of all political stripes, it might ultimately foster more extremism and instability than it successfully avoids.

\section{A. Public Reason's Narrowing of the Public Conversation}

How might this work? Theories of public reason operate by excluding categories of speech as well as, to a less but still very real degree, ideas and speakers from public debate. This is easiest to see with exclusive versions of public reason, which prohibit certain sorts of argument in relation to at least some categories of public discourse (typically public discourse aimed at the most fundamental and important issues a society confronts). Speakers who are unable adequately to translate their ideas into terms that satisfy the requirements of a particular, exclusive conception of public reason, and ideas whose translation into the language of public reason deprives them of some essential content, will therefore be wholly excluded from (or disabled within) the relevant public discussions. This inability to translate will most often, but not exclusively, be associated with particular religious traditions. ${ }^{87}$

Even for those who can "translate," however, exclusive conceptions of public reason can work to silence the central, and perhaps most compelling, elements of religious speakers' political beliefs and motives. An example frequently raised by critics of public reason, but no less compelling for the wear, is Martin Luther King's "I Have a Dream" speech. ${ }^{88}$ The famous oration has been described by one commentator as "a significant example of theo-political rhetoric distinguished by substantive elements of the concept of proclamation in the Judeo-Christian tradition . . ..,89

As Drew D. Hansen has recently observed, the prepared text of the speech "stayed close to standard themes from the political rhetoric of the $1960 \mathrm{~s}$

\footnotetext{
85 See supra note 44 , and accompanying text.

86 See Shiffrin, supra note 20, at 26; Quinn, supra note 67, at 50.

87 See Habermas, supra note 6, at 8-9; Smolin, supra note 6, at 1077-79.

88 See CARTER, supra note 6, at 228.

89 John H. Patton, "I Have a Dream": The Performance of Theology Fused with the Power of Orality, in MARTIN Luther King, JR., AND THE SERMONiC Power of Public Discourse 104, 104 (Carolyn Calloway-Thomas \& John Louis Lucaites eds., 1993).
} 
and the oratory of the civil rights movement: the appeal to American ideals, the protest against gradualism, the call for nonviolence and racial integration within the freedom movement." 90 Had King not extemporized to include the soaring prophetic imagery of the speech's conclusion, some of it drawn straight out of the Bible, "it is doubtful," Hansen argues, "that his speech at the end of the march would be remembered at all." 91 Robert N. Bellah and his co-authors concur in identifying the great power of the speech in King's amalgamation of "the poetry of the scriptural prophets . . . with the lyrics of patriotic anthems . . . "92 As John Patton observes, "[the] famous section of the speech where the dream becomes most specific is wrapped at the beginning in a secular abstraction ... and culminates in a universal theological abstraction."93 And yet the powerful, religiously infused political imagery of those concluding minutes-much of it spontaneously inserted by King as he spoke-is precisely the element of the speech that would most clearly fail to qualify under exclusive theories of public reasonableness. $^{94}$

Perhaps less intuitively, a process of exclusion operates-albeit to a more limited extent-even within so-called "inclusive" theories of public reason. Inclusive theories, like Solum's (and like Rawls's later versions of his theory) permit the assertion of nonpublic reasons provided that they are accompanied in due course by public reasons. But, as with exclusive theories of public reason, even inclusive theories exclude those who cannot (or, for reasons having to do with the content of their religious conception, will not) provide a reason that satisfies the requirements of publicity.

Karl Barth's evangelical moral theology, for example, conceives of human beings' knowledge of the good as rooted in their perception of a "command of God." 95 Barth understood this command as "immediate and direct guidance" about what to do that is apprehended within the context of a "personal encounter" between human being and God that is "immediate, direct, and intimate in form." 96 This apprehension of divine command is not mediated by moral theory and is therefore difficult, if not impossible, to translate into the language of public reason." As Robin Lovin describes Barth's ethics, "[ $t]$ he child of God

\footnotetext{
90 Drew D. HANSEN, ThE DREAM 135 (2003).

91 Id.

92 Robert N. Bellah et al., Habits of the Heart 249 (2d ed. 1996); see also Perry, PoLitics, supra note 2, at 48-49.

93 Patton, supra note 89 , at 114.

94 Rawls attempted to make some allowance in his theory of public reason for the use of religious language by proponents of abolition and civil rights. See RAWLS, supra note 2, at 249-50. The inadequacy of his explanation of the propriety of that language has been amply criticized elsewhere. See Sandel, supra note 48, at 1791; Shiffrin, supra note 20, at 31-32.

95 Nigel Biggar, The Hastening that WaITS 14 (1993).

$96 \quad$ Id. at 15.

97 See id. at 17-18 "This concept of the divine command allows room for only one legitimate kind of ethical reflection; not that which engages in theoretical enquiry into the nature of the good,
} 
knows in action what God's will requires, but this certainty is neither visible to his neighbor nor available for his own reflection." 98 A believer committed to Barth's conception of ethics would not be able to offer any publicly cognizable reason for her behavior, even in the form of a mediating moral principle. She would, in fact, view any such effort to explain her behavior without reference to divine command as improper. The Barthian believer would therefore be utterly excluded from public deliberation, even by inclusive accounts of public reason.

Inclusive theories of public reason also have a negative, though less dramatic, effect on those who are able to translate. To begin with, the need to translate certain sorts of arguments, but not others, into public terms casts an epistemological stigma over the non-public discourse. As Stephen L. Carter puts it, by "require[ing] the individual whose religious tradition makes demands on his or her moral conscience to reformulate that conscience . . . in order to gain the right to participate in the dialogue alongside other citizens," the "liberal world" indicates that it "regards religious knowledge of being of a decidedly inferior sort." 99 Carter's observation applies whether the conception of public reason requiring the reformulation is exclusive or inclusive. This stigma itself may discourage some religious believers-even those who can translate-from raising their religious arguments in public or from participating in public political debate at all.

Moreover, while inclusive theories would not categorically exclude religious content, they would still force religious speakers to accompany their most powerful arguments with language translating those arguments into the vocabulary of public reason, a process that will often result in the (forced) presentation of arguments that are less authentic and, as a consequence, less compelling. The assertion of the less persuasive public arguments-the price of admission into public discourse for an inclusive system of public reason-could undermine the credibility of the nonpublic arguments, which might themselves seem less forceful when juxtaposed with their more unconvincing translations.

Both exclusive and inclusive accounts of public reason, then, are likely to drive at least some religious speakers from the public square and to weaken the effectiveness of others. ${ }^{100}$ Moreover, inclusive versions of public reason place special discursive burdens on religious speakers who seek to participate in public discourse, burdens that are not shared by those predisposed to employ

but that which takes the form of self-examination. Through this form of reflection I ask myself 'at every moment of [my] willing and acting' whether my life has been and will be directed toward the telos of real humanity to which I have been elected in Jesus Christ . . .") (quoting 2 KARL BARTH, CHURCH DOGMATICS 566-67, 634-36, 641-42, 645-61 (1936)).

98 Robin Lovin, Christian Faith AND Public Choices 41 (1984).

99 CARTER, supra note 6, at 229.

100 This is less true of Habermas's theory of public reason, which applies only at the level of the institutional state, and would therefore permit the free participation of religious voices in the public debate, so long as religious arguments are translated into secular terms by someone before the institutional state itself adopts them as its own. See Habermas, supra note 6, at 8-11. 
secular (or otherwise public) arguments. The result of broad compliance with theories of public reason-of either variety-will predictably be that a number of religious speakers who otherwise might have participated in public discourse will be excluded or will voluntarily disengage. In the United States, where a large portion of the population identifies itself as religious, the scope of this exclusion would likely be nontrivial. ${ }^{101}$

\section{B. The Deliberative Consequences of Public Reason's Exclusions}

The exclusion worked by public reason-whether self-inflicted or imposed by others-might generate a number of negative consequences for the quality of public (and private) deliberation and for social stability. I will focus on two: the way in which the silencing of religious voices in the public sphere might operate to inhibit the initiation of public deliberation and, second, the way in which the exclusion worked by public reason might distort the content and outcome of that deliberation once it begins.

\section{Deliberative Inhibition}

Proponents of public reason focus their attention on the ideal rules of behavior within conversations between people committed to different comprehensive conceptions of the good. But by emphasizing the rules of debate once discussion is underway, these theorists ignore the difficulty of getting public conversations started in the first place. In setting onerous preconditions for participation in public deliberation among people who think radically differently from each other, however, proponents of public reason may be fixating on the far less salient barrier to ecumenical dialogue. ${ }^{102}$

People are generally predisposed to seek out conversation primarily with those who already think like them. ${ }^{103}$ This is at least in part because conversing, particularly with those with whom we disagree, is hard work. Most people would rather go about their business working, playing, and otherwise living their lives. Conversation starting is therefore something of a public good that is, like many public goods, prone to underproduction in the absence of appropriate incentives or social norms. Moreover, because beneficiaries of the status quo often have very little interest in talking about change, conversation

\footnotetext{
101 See EBERLE, supra note 2, at 184; Habermas, supra note 6, at 2; Shiffrin, supra note 20, at 30 ("Ninety percent of Americans believe in God."). I agree with Shiffrin, however, that there is little danger of widespread compliance with restrictive versions of public reason, especially on the part of religious conservatives.

102 I borrow the term "ecumenical" to refer to inter-tradition dialogue from Michael Perry's Love and Power, ch. 6 (1991).

103 See CASS SUNSTEIN, REPUBLIC.COM 56-60 (2001) ("[T]here is a natural human tendency to make choices, with respect to entertainment and news, that do not disturb our preexisting view of the world.").
} 
starting is particularly challenging when the subject under discussion is an injustice from which the majority (or an established oligarchy) profits at the expense of a minority (or powerless majority).

In this country, religious thought has consistently played an important role in generating the emotion and commitment necessary to push people beyond themselves so as to motivate them to initiate and participate in crucial public discussions. Numerous commentators from Alexis de Tocqueville to the present-day have agreed that one of the crucial functions that religious communities have served has been to counteract "the ever present tendency of citizens in an economically prosperous democracy to privatize their lives by immersing themselves exclusively in commercial pursuits." 104 "There is no religion," de Tocqueville observed, "which does not ... impose on man some duties toward his kind, and thus draw him at times from the contemplation of himself." Robert Bellah and his co-authors note, this tendency of religion to push people outside themselves has propelled religious communities toward the center of virtually every important social movement in American history. "[W]ithout the intervention of the churches," Bellah argues, "many significant issues would have been ignored and needed changes would have come about much more slowly."106 Far from being an inherent conversation stopper, religious discourse has started some of the most important conversations in our nation's history. ${ }^{107}$

This observation is not susceptible to Eberle's objection that arguments defending religious discourse in public life on the basis of religious groups' past involvement in social movements necessarily rest on an unjustifiably rosy conception of religion's net moral impact. On Eberle's view, pointing out that religious communities have been at the heart of important social movements is only an effective counter to restrictive accounts of public reason if, on balance, religious interventions have occurred on the right moral side of the moral debates. ${ }^{108}$ Eberle is surely correct that " $[t]$ here is . . no uncontroversial way to

104 Christopher F. Mooney, Public Virtue X (1986) (quoted in Hollenbach, supra note 7, at 93); see also BELLAH ET AL., supra note 92, at 223.

105 AleXis de ToCQUeVIlLe, Democracy IN AMERICA 152 (Richard D. Heffner ed., 1984).

106 BELLAH ET AL., supra note 92, at 249; see also WEITHMAN, supra note 84, at ch. 2 (discussing the role of religion in promoting democracy).

107 Relatedly, theorists of public reason may unduly privilege a rationalist account of public deliberation. As the Civil Rights movement amply demonstrates, passion, and not reason, may be precisely what the doctor orders to get entrenched injustice on the public's deliberative table. See Shiffrin, supra note 47 , at 1634 . Public reason's elevation of measured rationality as the sine qua non of fruitful public discourse seems to rest on an artificially narrow understanding of how public discussion operates. If many of the most passionate voices have been silenced, controversial but necessary deliberation may have a great deal of difficulty even getting off the ground. By encouraging the withdrawal, at least in part, of religious speakers from public deliberation, proponents of public reason may unwittingly work to protect existing injustice against public debate in a way that allows it to fester and perhaps sows the seeds for future instability.

108 See EBERLE, supra note 2, at 176. 
determine where on the continuum that ranges between angelic good and demonic evil we ought to place a given crusade." 109

Contrary to Eberle, however, the observation that religious communities have played a crucial conversation-starting role-or that the reduction of public conversations that would result from religious privatization would constitute a social harm-does not depend on the premise that religious groups, on balance, tend to stake out the morally correct position within those conversations. The argument is not that religious communities are, over the run of cases, more likely than other groups to be on the right side of issues. After all, as Bellah notes, religious groups have been on both sides of virtually every important social movement in American history. ${ }^{110}$ The argument I am making is instead a second-order argument that public engagement is an affirmative good. It is, however, a good that is perennially likely to be in short supply, and the shortage of that engagement is, at least within a democracy, a cause for concern. ${ }^{111}$ Religious commitment helps to generate public engagement. Even when religious groups (rightly) end up on the losing side of a debate they helped to instigate, society benefits from the debate having occurred.

\section{Deliberative Distortion}

Not only might adherence to the requirements of public reason inhibit the initiation of public deliberation, but, by systematically depriving public discourse of certain types of religious perspectives, public reason might impoverish that deliberation once it begins. When homogeneous groups deliberate, their members have a tendency to settle on conclusions that are more extreme-and less reliable ${ }^{12}$ - than those they espoused as individuals prior to the deliberation. ${ }^{113}$ This is because speakers within a homogenous group feel social pressure to conform to the views being expressed by members of the group and because homogeneity restricts the "argument pool" to which group members are exposed. ${ }^{114}$

The exclusion of certain religious points of view from public discourse may therefore diminish the quality of the deliberation both of those who participate in the public conversation as well as those who are excluded. Applying Sunstein's model, public discussions will yield less reliable results as the pool of discussants becomes narrower. In this case, the exclusion of certain religious points of view could have the effect of pushing the public discussion in secular

\footnotetext{
109 Id.

110 See BELLAH ET AL., supra note 92, at 248-49.

111 As Justice Louis D. Brandeis put it, "the greatest menace to freedom is an inert people." Whitney v. California, 274 U.S. 357, 375 (1927) (Brandeis, J., concurring).

112 See PAGE, supra note 9, at 157-65.

113 See SUNSTEIN, supra note 103, at 65-69, 72; Sunstein, supra note 73, at 176.

114 Sunstein, supra note 73 , at 176-77.
} 
directions as the requirements of public reason-in both its exclusive and inclusive forms-increase the profile of nonreligious arguments relative to religious ones and systematically exclude the religious voices of those who cannot translate and push to the margins the religious arguments of those who can. If people abide by the rules of public reason, public deliberation will make the world seem like a more secular place than it actually is, and the solutions on which participants settle within that public conversation will likely shift toward those favored by secular thought. This shift will likely have substantive consequences because, as Habermas points out, "[r]eligious traditions have a special power to articulate moral intuitions, especially with regard to vulnerable forms of communal life." 115

Nor would the distortion worked by the exclusion of religious voices be neutral with respect to race and class. As Paul J. 'Veithman and David Hollenbach have observed, the distortion generated by the exclusion of religious voices from the public square would likely exacerbate racial and economic inequality in political influence in the United States. ${ }^{16}$ Drawing on the research of Sidney Verba and other social scientists, Weithman notes that the exclusion of religious voices would disproportionately silence African-Americans and the poor, both of whom benefit enormously from churches' egalitarian inculcation of civic engagement and skills." "The weight of the counterbalance black churches provide to offset other sources of African-American political inequality," Weithman pointedly observes, "presses the question of what other institution would play this function if churches ceased to play a prominent political role." 118

At the same time, restrictive accounts of public reason would distort the deliberation of those who withdraw or are discouraged from participating in the public conversation. After all, those groups are likely to (re)turn toward conversation with those who think more like them, with the result that they will be less likely to find their own presuppositions challenged by divergent voices. Moreover, the perception among the disfavored groups that they have been wronged by the rules of public debate will likely exacerbate the distorting effects of exclusion. ${ }^{119}$ The excluded, nonpublic groups will therefore predictably find their own private conversations tending to diverge from the broader public's. Within such enclaves, isolated from the moderating effects of public engagement, the risk of extremism will increase. ${ }^{120}$ Or, as Michael Sandel has put it, "[f]undamentalists rush in where liberals fear to tread." 121

\footnotetext{
115 Habermas, supra note 6, at 10.

116 See HollenBach, supra note 7, at 180-81; WeITHMAN, supra note 84, at 40-48; see also SIDNEY VERBA ET AL., VOICE AND EQUALITY 320 (1995).

117 See WEITHMAN, supra note 84 , at $45-48$.

118 Id. at 48.

119 See EBERLE, supra note 2, at 184.

120 See Sunstein, supra note 73, at 191 ("It is total or near-total self-insulation, rather than group deliberation as such, that carries with it the most serious dangers, often in the highly unfor-
} 
We can get a taste of the distorting effects that restrictive accounts of public reason may have on political deliberation by considering the relative quiescence of the religious left over the past few decades. (This is where my argument converges with Shiffrin's.) Although progressive religious voices were extremely prominent during the Civil Rights Movement, ${ }^{122}$ in recent years they have been far less audible, perhaps in part in response to the growing consensus among the liberal intelligentsia that religious discourse does not belong in the political sphere. ${ }^{123}$ The relative silence of this distinctive voice within the American political conversation has perhaps contributed to what commentators have perceived as a rising hostility to religion within the American left. ${ }^{124}$ That is, with the decline of forceful religious voices in liberal circles, due at least in part to the self-restraint advocated by proponents of public reason, the left has arguably drifted in a decidedly secular direction, just as Sunstein's model predicts. This distortion of progressive political discourse is mirrored by a corresponding tendency to identify conservatism with religiosity, resulting in a contemporary political culture characterized by a sharp polarization between an increasingly secular left and a "religious right.", 25

Once this polarization takes root, it can become perniciously selfreinforcing. Conservative voices come to be seen as authentically "religious" in a way that progressive religious voices are not, precisely because we are more accustomed to hearing them. Eventually, even when religious progressives speak, they are ignored or written off as anomalous by those who control the means of communication. It is not altogether surprising then, that, as one recent study has found, religious voices in the mainstream media disproportionately represent conservative political points of view. ${ }^{126}$

Several scholars have correctly argued that the solution to this distortion is not public reason's proposal to restrict religious political expression from the

tunate (and sometimes deadly) combination of extremism with marginality."); see also Solum, supra note 14 , at $748-49$. This is not to deny the value of the diversity of communal voices that arise when groups retreat into isolated deliberation away from the moderating effects of the broader society, a phenomenon that Sunstein helpfully dubs "enclave deliberation." Sunstein, supra note 73, at 177. Arguably, to be healthy, a system of deliberation requires a balance of both (1) protected private enclaves to which communities of discourse can retreat to formulate and refine their diverse conceptions of the good, even radical conceptions, and (2) public spaces that provide disparate groups with the opportunity to come together to interact and debate.

121 Sandel, supra note 48, at 1794.

122 See CARTER, supra note 6, at 227-29.

123 See Jim Wallis, Let's Clear the Air, Beliefnet, http://www.beliefnet.com/blogs/godpolitics/ 2007/02/jim-wallis-lets-clear-air.html (last visited Feb. 23, 2007).

124 See id.; see also Shiffrin, supra note 20, at 1 ("In recent years the dominant media picture of the relationship between religion and the left has been one of hostility, estrangement, and suspicion.").

125 Quinn, supra note 67, at 50.

126 See Media Matters for America, Left Behind (unpublished manuscript), available at http://mediamatters.org/leftbehind/). 
right - which is, if anything, a utopian fantasy-but rather the reinvigoration of progressive religious voices. ${ }^{127}$ In Philip L. Quinn's words, only religious progressives can "argue for liberal laws and policies from religious premises and thereby show secular liberals that some religious people are their allies, and they would also be in a position to dispute the political agenda of the Religious Right on religious grounds." 128 In so doing, religious progressives could challenge the current self-understanding of American politics as a contest between a secular left and a religious right. When scholars like Quinn argue along these lines, they are implicitly drawing on the happy story and the affiliated model of public deliberation I am describing.

None of this is to deny that homogeneity can have its benefits. Scott Page has argued, for example, that deliberative outcomes improve when people bring a variety of intellectual tools (what he calls "toolbox diversity") to the task of solving problems that stand in the way of accomplishing certain goals. ${ }^{129}$ But he is careful to observe that diversity of preferences and values ("preference diversity") can generate conflict over what count as the right goals to begin with. ${ }^{130}$ Of course, as he also points out, the existence of preference diversity is not itself unrelated to the existence of toolbox diversity, as the pursuit of different preferred goals is likely to lead people to develop different sets of intellectual tools. $^{131}$ In other words, diversity is a complex phenomenon that generates both costs and benefits, often at the same time. Whether the benefits of deep normative diversity outweigh its costs is a difficult question that may not lend itself to a single answer for all times and places. ${ }^{132}$

This country's experience of economic prosperity and (relative) religious peace, even as religious diversity exploded over the course of the twentieth century, and despite the utter absence of the ethic of self-restraint demanded by theories of public reason, provides at least some reason to think that, for our particular society, the beneficial effects of pluralism outweigh its costs. At the same time, it calls into question assertions that the restraints of public reason are necessary to hold our democracy together. ${ }^{133}$ Nor is it clear that the sort of hyper diversity that appeared in the United States over the course of the last century is a particularly virulent version of pluralism that calls for radical measures. Indeed, it may be the case that the threat posed by diversity to stability is far

\footnotetext{
127 Id.; see also Shiffrin, supra note 20, at 26.

128 Quinn, supra note 67, at 50.

129 See PAGE, supra note 9, at 11.

130 See id.

131 See id. at 286 ("When we say that people have diverse preferences, we will mean that we have different goals, desires, wants, and needs. And we acquire diverse cognitive tools to satisfy these preferences .... Preference diversity begets toolbox diversity. And therefore, preference diversity has a strong and positive effect on problem solving.").

132 See id. at 331-34; GrEENAWALT, supra note 2, at 6.

133 See PERRY, POLITICS, supra note 2, at 53 n.37 (quoting Lawrence B. Solum, Faith and Justice, 39 DEPAUL L. REV. 1083, 1096 (1990)).
} 
more grave when the degree of pluralism is mild and the cleavages are few in number. It is worth more than a passing notice that the societies that engaged in the sixteenth century religious bloodletting were, if anything, far more religiously homogeneous than our own and that our most diverse communities-our cities-are also by and large our most tolerant. ${ }^{134}$

Moreover, as it turns out, our own Constitution's treatment of religious pluralism seems an ideal match with a society operating according to the happy story. By simultaneously prohibiting the establishment of religion and protecting the right to exercise one's religion, the First Amendment dramatically lowers the stakes of permitting religious participation in public discourse. ${ }^{135} \mathrm{Al}$ though there is obviously a great deal of controversy about how to understand what the Constitution means by "establishment" and "free exercise," the outer limits of the terms, that is, the applications on which almost everyone agrees, go a great distance toward declawing public religious disputes. On the establishment side, the Constitution removes the most powerful incentives for religious groups to try to gain control of the state. On the free exercise side, even under the flawed regime of Employment Division, Department of Human Resources of Oregon $v$. Smith, ${ }^{136}$ the Constitution protects minority religious groups from the most egregious sorts of abuses. ${ }^{137}$ Some of the more alarming predictions by proponents of restrictive conceptions of public reason lose their bite with the Religion Clauses operating in the background. ${ }^{138}$ The existence of the Religion Clauses therefore takes some of the pressure off the discussions of the role of religion in public discourse and reduces the risks to social peace of adopting a relatively laissez faire position on public reason. ${ }^{139}$

\section{CONCLUSION}

Proponents of public reason tend to treat the elimination of the divisiveness of religion (or other nonpublic argument) from public deliberation as an unmitigated good. ${ }^{140}$ But, as models of public deliberation consistent with the happy story of pluralism demonstrate, the exclusion of religious points of view is not without its potential costs. By pushing religious speech and thought to the margins, public reason may prevent certain important discussions from ever

\footnotetext{
134 See Ross, supra note 83, at 164-65; Miller, supra note 80, at 735.

135 See EBERLE, supra note 2, at 161-62; MOONEY, supra note 104, at 28-29.

136494 U.S. $872(1990)$.

137 See Church of the Lukumi Babalu Aye, Inc. v. Hialeah, 508 U.S. 520,532 (1993) ("At minimum, the protections of the Free Exercise Clause pertains if the law is at issue discriminates against some or all religious beliefs or prohibits conduct because it is undertaken for religious reasons.").

138 See Shiffrin, supra note 47 , at 1645 (arguing that in order for religion to become a destabilizing force, the Constitution would have to be changed in fundamental ways).

139 See id.

140 But see Solum, supra note 14 , at 748-49.
} 
taking place and may undermine the beneficial impacts of pluralism on those that do.

Whether, from the point of view of stability and deliberative outcomes, the negative consequences of exclusion outweigh its benefits is, ultimately, a difficult empirical question. The debate over public reason, however, has taken place in the nearly complete absence of any real empirical inquiry or discussion. Without solid evidence, we can only speculate, but it is at least plausible to suppose that the negative consequences for stability and deliberation of excluding (and encumbering) religious voices might outweigh the benefits. In short, it may well turn out that, at the end of the day, a mere modus vivendi might be more stable than a true overlapping consensus.

The happier story about the relationship between diversity and pluralism seems to lend itself to what scholars have described as a "laissez faire" position within the debate over public reason, at least with respect to political discourse by normal citizens and, perhaps, by legislators. ${ }^{14 I}$ The happy story does not, of course, mandate that position. This is in part because of the tentativeness of its empirical foundations, but it is also because the happy story is not responsive to the arguments about legitimacy raised by public reason's proponents.

As I noted at the outset, I am sympathetic with arguments other theorists have raised against the accounts of legitimacy on which the more restrictive theories of public reason rely. But my purpose in writing this paper was to narrowly explore the relationship between public reason and stability, and, at least on that score, the case for the salience of the happy story does call into question the claims that theorists of public reason have made about the destabilizing effects of religious discourse within the public conversation. Consequently, and as Waldron has suggested, the happy story at a minimum cautions us against reflexively supporting broad restrictions on religious participation in public discourse, particularly if we do so in the hope of avoiding social conflict. ${ }^{42}$

As I have argued in this paper, content-based restrictions on participation in public debates might well have the opposite effect from what their proponents expect. They might degrade public debate and polarize political positions, rather than enhancing the quality of deliberation and bringing people together. Perhaps legitimacy-focused proponents of public reason will view the risk of such deliberative harm to be a price worth paying to realize their concep-

141 The details of the application of such a model of public reason, and its fit with possible readings of the Establishment Clause, are beyond my ambitions for this essay. Suffice it to say that I agree with efforts to resist the exclusion of overtly religious argument from legislative debate, although I am sympathetic with the exclusion, on establishment grounds, of overtly religious reasons from the official "acts" of government bodies, including legislatures. I would therefore support the prohibition of explicitly religious appeals from "whereas" clauses and legislative histories.

142 See Waldron, supra note 54 , at 837. 
West Virginia Law Review, Vol. 110, Iss. 1 [2007], Art. 23

544

WEST VIRGINIA LAW REVIEW

[Vol. 110

tion of political justice, but it is a price that they should at least acknowledge in their analyses, even if only to disregard it in the end. 